\title{
Hierarchical CuO/ZnO Membranes for Environmental Applications under the Irradiation of Visible Light
}

\author{
Zhaoyang Liu, Hongwei Bai, and Darren Delai Sun \\ School of Civil \& Environmental Engineering, Nanyang Technological University, Singapore 639798 \\ Correspondence should be addressed to Zhaoyang Liu, zyliu@ntu.edu.sg and Darren Delai Sun, ddsun@ntu.edu.sg
}

Received 19 June 2011; Accepted 14 September 2011

Academic Editor: Jae Sung Lee

Copyright () 2012 Zhaoyang Liu et al. This is an open access article distributed under the Creative Commons Attribution License, which permits unrestricted use, distribution, and reproduction in any medium, provided the original work is properly cited.

Solar visible light is a source of clean and cheap energy. Herein, a new kind of hierarchical $\mathrm{CuO} / \mathrm{ZnO}$ nanomaterial was synthesized using a facile process. Characterized by FESEM, TEM, XRD, XPS, and so forth, this CuO/ZnO naomaterial shows a special hierarchical nanostructure with $\mathrm{CuO}$ nanoparticles grown on $\mathrm{ZnO}$ nanorods. By assembling the hierarchical $\mathrm{CuO} / \mathrm{ZnO}$ nanomaterials on a piece of commercial glassfiber membrane, a novel hierarchical $\mathrm{CuO} / \mathrm{ZnO}$ membrane was fabricated. This $\mathrm{CuO} / \mathrm{ZnO}$ membrane demonstrated excellent environmental applications, such as improved photodegradation of contaminants and antibacterial activity, under the irradiation of visible light. Compared with pure $\mathrm{ZnO}$ nanorod membrane, the improved photodegradation and antibacterial capacities of this hierarchical $\mathrm{CuO} / \mathrm{ZnO}$ membrane result from the special hierarchical nanostructure of $\mathrm{CuO} / \mathrm{ZnO}$ nanomaterials, which could enhance light utilization rate, enlarge specific surface area, and retard the recombination of electrons and holes at the interfacial between $\mathrm{CuO}$ and $\mathrm{ZnO}$. This hierarchical $\mathrm{CuO} / \mathrm{ZnO}$ membrane is also easy to be regenerated by completely mineralizing the adsorbed contaminants under the irradiation of visible light. All the above characteristics of this hierarchical $\mathrm{CuO} / \mathrm{ZnO}$ membrane indicate its great potential in environmental applications with solar visible light.

\section{Introduction}

Widespread water source contamination and increasing demand for consumable water necessitate a novel and sustainable approach to the remediation of polluted water [1]. Photocatalytic nanomaterials have shown high efficiency in contaminant removal through the degradation of organic contaminants and the inactivation of bacteria [2-4]. Solar energy is a clean and renewable resource ideal for environmental and sustainable applications. Photocatalytic degradation utilizing visible light radiation is an increasingly popular research topic [5]. $\mathrm{ZnO}$ is an extensively studied semiconductor employed in the photocatalytic removal of contaminants in water $[6,7]$. However, pure $\mathrm{ZnO}$ nanomaterials have limited efficiency because of the low light utilization rates resulting from the wide-band gap $(3.2 \mathrm{eV}) . \mathrm{ZnO}$ nanomaterials absorb only a small portion of light in the UV spectrum and exhibit rapid recombination of electrons and holes reducing their photocatalytic activity $[8,9]$. The key to broadening the applications for $\mathrm{ZnO}$ nanomaterials lies in overcoming these shortcomings. Over several decades, efforts have been made to enhance the photocatalytic activity of $\mathrm{ZnO}$ through metal [10] or carbon/nitrogen doping [4, 11]. $\mathrm{ZnO}$ nanomaterials have also been coupled with narrowband gap semiconductors like $\mathrm{Fe}_{2} \mathrm{O}_{3}, \mathrm{WO}_{3}, \mathrm{CdS}, \mathrm{Cu}_{2} \mathrm{O}$, and $\mathrm{CuO}$ in attempts to improve photocatalytic activity by encouraging red shift [12-16]. The resulting increase in wavelength produces light in the visible spectrum, thereby, increasing light absorption and retarding electron and hole recombination. $\mathrm{ZnO}$ has also received attention for its antibacterial properties through a mechanism which destroys the cell membrane affecting bacterial morphology and the efflux of intracellular components [3].

Hierarchically structured nanomaterials with multiscaled organizations increase light reflection and absorption inside the material to enhance light utilization rate and enlarge specific surface area [17]. This effectively increases contaminant attachment and adsorption. These attributes make hierarchical nanomaterials a desirable approach to enhancing photocatalytic activity [18]. 
In practical application, the recovery of the photocatalyst from treated water is an important economic and sustainability consideration. The incorporation of the photocatalyst into a functional membrane is an ideal approach as it facilitates convenient recovery and regeneration whilst degrading foulants retained in pores or on the membrane surface by simple irradiation using either UV or visible light $[19,20]$. It is meaningful to fabricate a multifunctional membrane for contaminant removal via photodegradation and inactivation of bacterial under the irradiation of visible light. The multiple functions of such a membrane comes from the functional layer created by a hierarchical structured $\mathrm{CuO} / \mathrm{ZnO}$ materials, which could demonstrate high photocatalytic activity because of the enhanced light utilization rate, enlarged specific surface area, and the efficient antirecombination of electrons and holes. In this case, the photocatalysts are easy for reuse, and the multiple functional membrane is easy to be regenerated after complete mineralization of the adsorbed contaminants via extending the irradiation time of visible light.

In this study, a new kind of hierarchical $\mathrm{CuO} / \mathrm{ZnO}$ nanomaterials is synthesized using low-temperature hydrothermal and photodeposition process. A piece of multifunctional membrane is fabricated by assembling the hierarchical $\mathrm{CuO} / \mathrm{ZnO}$ nanomaterials on top of a piece of commercial glassfiber membrane. Under the irradiation of visible light, this functional membrane demonstrated better photodegradation of contaminants and bacterial inactivation over a comparative functional membrane with a pure $\mathrm{ZnO}$ layer. This membrane is also characteristically easy to regenerate and has high reusability. All the above characteristics indicate its good potential in environmental purification with the usage of solar energy.

\section{Experimental Section}

\subsection{Materials Synthesis}

2.1.1. The Synthesis of $\mathrm{ZnO}$ Nanorods. Zinc acetate dihydrate $\left(\mathrm{Zn}\left(\mathrm{CH}_{3} \mathrm{COO}\right)_{2}, 2 \mathrm{H}_{2} \mathrm{O}\right)$ was purchased from Alfa, hexamethylenetetramine (HMTA: $\mathrm{C}_{6} \mathrm{H}_{12} \mathrm{~N}_{4}$ ) was purchased from Sigma, and copper sulfate $\left(\mathrm{Cu}\left(\mathrm{SO}_{4}\right)_{2} \cdot 5 \mathrm{H}_{2} \mathrm{O}\right)$ was from Alfa. Other chemicals were purchased from Sigma. According to the reports [21-23], a mixed solution of $0.03 \mathrm{M}$ $\mathrm{Zn}\left(\mathrm{CH}_{3} \mathrm{COO}\right)_{2}$ and $0.03 \mathrm{M}$ HMT was well prepared, and adjusted the $\mathrm{pH}$ of the solution around 7.5. $100 \mathrm{~mL}$-mixed solution was filled in a high temperature resistance glass bottle $\left(<140^{\circ} \mathrm{C}\right)$ and sealed tightly. After hydrothermally treated for $6 \mathrm{~h}-12 \mathrm{~h}$ at $95^{\circ} \mathrm{C}$, the precipitation at the bottom of the glass bottle was collected and sufficiently washed for further characterization and usage.

\subsubsection{The Synthesis of $\mathrm{CuO} / \mathrm{ZnO}$ Hierarchical Nanomaterials.} A given amount of hydrothermally synthesized $\mathrm{ZnO}$ nanorods were dispersed in $100 \mathrm{~mL}$ deionized (DI) water. $0.1 \mathrm{~g}$ $\mathrm{Cu}\left(\mathrm{SO}_{4}\right)_{2}, 5 \mathrm{H}_{2} \mathrm{O}$, and $0.1 \mathrm{~g} \mathrm{NaCl}$ were added in the solution and were continuously stirred for $10 \mathrm{~min}$ and ultrasonicated for another $10 \mathrm{~min}$ to make a mixed solution [24]. A weak

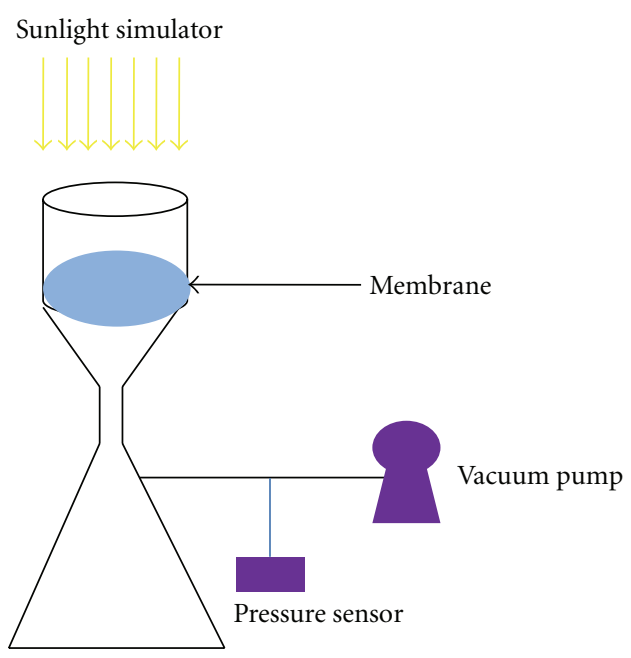

Scheme 1: Schematic setup for membrane assembly and photodegradation of contaminants.

black UV light with a predominant wavelength of $365 \mathrm{~nm}$ was suspended at the middle of the solution [25]. Under the continuous stirring, the mixed solution was illuminated for 6-12 h. Collect the precipitations at the bottom and wash them with DI water sufficiently. After being calcined at $500^{\circ} \mathrm{C}$ for $1 \mathrm{~h}$ in a furnace under atmospheric condition, the samples were ready for further characterizations and environmental application tests.

\subsubsection{Assembly of the Hierarchical $\mathrm{CuO} / \mathrm{ZnO}$ Multifunctional} Membrane. $100 \mathrm{mg}$ of synthesized hierarchical $\mathrm{CuO} / \mathrm{ZnO}$ nanomaterials were dispersed in $100 \mathrm{~mL}$ DI water. One piece of commercial glass fiber membrane (Adventc discs $\varnothing 47 \mathrm{~mm}, 0.50 \mu \mathrm{m})$ was mounted at the bottom of the vacuum filtration cup (Scheme 1), then slowly poured the mixed solution into the filtration cup and switched on the vacuum pump. After certain time, the water was filtrated away, leaving a uniformly assembled membrane with the $\mathrm{CuO} / \mathrm{ZnO}$ hierarchical materials. This membrane is named as $\mathrm{CuO} / \mathrm{ZnO}$ membrane. As a comparison, a piece of pure $\mathrm{ZnO}$ membrane with $\mathrm{ZnO}$ nanorods was assembled by the same method; this membrane is named as $\mathrm{ZnO}$ membrane.

2.1.4. Photodegradation Test. Three kinds of commonly used pollutants, including methyl blue (MB), acid orange (AO7), and Rhodamine $\mathrm{B}(\mathrm{RhB})$ aqueous solution, were used for the test. The experiment detail was as follows. Firstly, the aqueous solutions of $\mathrm{MB}(100 \mathrm{mg} / \mathrm{L}), \mathrm{AO} 7(50 \mathrm{mg} / \mathrm{L})$, and $\mathrm{RhB}(50 \mathrm{mg} / \mathrm{L})$ were prepared, respectively; then the solution $(50 \mathrm{~mL})$ was poured into the filtration cup, at the bottom of which the $\mathrm{CuO} / \mathrm{ZnO}$ membrane was mounted, then let it adsorb for $1 \mathrm{~h}$ to reach adsorb equilibrium. Then switch on the sunlight simulator $(100 \mathrm{~mA})$ to start the photodegradation experiment. The whole test system is a continuous process. At a given internal, $3 \mathrm{~mL}$ reactant solution was drawn with a syringe, and its UV-visible adsorption value was measured by a UV-visible photospectrometer. As 
a comparison, the photodegradation ability of $\mathrm{ZnO}$ membrane was also tested using the same methods as above.

The concurrent photocatalysis and membrane filtration experiment was conducted, and the permeate quality was monitored by measuring the UV-visible adsorption value of the collected permeate at a given internal.

The photolysis experiment without $\mathrm{CuO} / \mathrm{ZnO}$ nanomaterials and $\mathrm{ZnO}$ nanorods was also carried out before each photodegradation experiment.

2.1.5. Antibacterial Test. Microorganism (E. coli) was cultivated in sterilized LB broth culture and then incubated overnight at $37^{\circ} \mathrm{C}$ with a shaking incubator. The concentration of E. coli was $10^{7} \mathrm{CFU} / \mathrm{mL}$. Before the antibacterial test, one new $\mathrm{CuO} / \mathrm{ZnO}$ membrane was assembled, and then the whole vacuum filtration setup except the sunlight simulator was sterilized in a UV-sterilization fume hose. The antibacterial capability of the $\mathrm{CuO} / \mathrm{ZnO}$ membrane was investigated with/without the irradiation of visible light after $40 \mathrm{~mL}$ E. coli solution was poured into the filtration cup (without switching on the vacuum pump). At an internal of $5 \mathrm{~min}, 1 \mathrm{~mL}$ reactant solution was drawn with a sterilized syringe and uniformly streaked on the well-solidified agar nutrient plate. After overnight's cultivation at $37^{\circ} \mathrm{C}$, the colonies were counted.

At the same time, the antibacterial capability of the $\mathrm{ZnO}$ membrane and the blank control experiment (without $\mathrm{CuO} / \mathrm{ZnO}$ nanomaterials and $\mathrm{ZnO}$ nanorods) with/without the irradiation of visible light were also carried out using the same methods as above.

2.1.6. Characterizations. The structure and the crystal phase of the synthesized $\mathrm{ZnO}$ nanorods, and the $\mathrm{CuO} / \mathrm{ZnO}$ hierarchical nanomaterials were analyzed by powder X-ray diffractometer (XRD, Bruker AXS D8 advance) with monochromated high-intensity $\mathrm{Cu} \mathrm{K} \sigma$ radiation $(\lambda=1.5418 \AA)$ operated at $40 \mathrm{kV}$ and $30 \mathrm{~mA}$. The obtained XRD spectra were matched with a powder diffraction file (PDF) database maintained by the International Centre for Diffraction Data (ICDD). The morphology of the samples was characterized by field emission scanning electron microscopy (FESEM, JEOL JSM-6360F) and high resolution transmission electron microscopy (HRTEM, Jeol JEM-2010). The element contents of the samples were measured by energy dispersive Xray spectrometer (EDS) attached to the SEM. The UV-Vis diffuse reflectance spectra of the samples were measured by a Thermo Scientific Evolution 300 UV-Vis spectrophotometer (Thermo Fisher Scientific, Mass, USA) equipped with an integrating sphere assembly and a Xenon lamp source. $\mathrm{BaSO}_{4}$ was used as the reflectance standard. The BET specific surface areas of the samples were determined at liquid nitrogen temperature $(77 \mathrm{~K})$ using a Micromeritics ASAP 2040 system. Before the measurement, $0.1 \mathrm{~g}$ sample was outgassed under vacuum for $6 \mathrm{~h}$ at $250^{\circ} \mathrm{C}$.

XPS analysis was carried out at room temperature in an ultra high vacuum (UHV) chamber with a base pressure below $2.66 \times 10^{-7} \mathrm{~Pa}$. Photoemission spectra were recorded by a Kratos Axis Ultra spectrometer (Shimadzu Corporation, Kanagawa, Japan) with a monochromatic $\mathrm{Al} \mathrm{K} \alpha$ excitation source $(h v=1486.71 \mathrm{eV})$. Curve fitting was performed using a nonlinear least square Gaussian-Lorenzian function. Carbon calibration shift was carried out at $284.6 \mathrm{eV}$ to remove the presence of residual adventitious carbon.

\section{Results and Discussions}

The morphology of the hydrothermally synthesized $\mathrm{ZnO}$ nanorods was observed by FESEM in Figure 1(a). It can be seen that the $\mathrm{ZnO}$ nanorod has a length of 10 to $20 \mu \mathrm{m}$, and the average diameter is around $1 \mu \mathrm{m}$, so the aspect ratio of length to diameter was around 10 to 20 , which belongs to a typical rod-like structure. And the synthesized $\mathrm{ZnO}$ nanorod has a smooth surface with a hexagonal end. The HRTEM image in Figure 1(b) obviously confirmed that $\mathrm{ZnO}$ grew along the direction of [0001] plane forming a rod like structure with a typical lattice of $0.52 \mathrm{~nm}$.

With the illumination of weak black light on the mixed solution of copper sulfate, sodium chloride, and $\mathrm{ZnO}$ nanorods, $\mathrm{Cu}$ nanoparticles were uniformly deposited on the surface of the $\mathrm{ZnO}$ nanorods. The $\mathrm{CuO} / \mathrm{ZnO}$ nanomaterials were well observed by FESEM as shown in Figures 2(a)-2(c) at different magnifications. These $\mathrm{Cu}$ nanoparticles are supposed to nucleate from the defect parts of the $\mathrm{ZnO}$ nanorods and grow up. After the illumination, the $\mathrm{ZnO}$ nanorods were thoroughly covered by $\mathrm{Cu}$ nanoparticles, forming a "cornlike" architecture. The followed calcination at $500^{\circ} \mathrm{C}$ for $1 \mathrm{~h}$ makes $\mathrm{Cu}$ become $\mathrm{CuO}$ without changing the morphology of the $\mathrm{Cu}$ nanoparticles, as shown in Figure 2(a). The sizes of the $\mathrm{CuO}$ nanoparticles were around $100 \mathrm{~nm}$. From Figure 2(b), it is found that only partial surface of the $\mathrm{ZnO}$ nanorod was covered by $\mathrm{CuO}$ nanoparticles. The distance between individual $\mathrm{CuO}$ nanoparticle was in the range of nanoscale, but the distance between individual $\mathrm{CuO} / \mathrm{ZnO}$ nanorod was in the range of microscale. Therefore, these $\mathrm{CuO} / \mathrm{ZnO}$ nanomaterials form a kind of hierarchical structure, which possesses the advantages of promoting mass transfer, enlarging the specific surface area, and promoting the charge transfer from $\mathrm{ZnO}$ nanorod to $\mathrm{CuO}$ nanoparticle. The energy disperse X-ray spectrum of the $\mathrm{CuO} / \mathrm{ZnO}$ hierarchical material $(\mathrm{Cu}(10 \mathrm{wt} \%))$ in Figure 2(c) clearly proved that the elements of $\mathrm{Zn}, \mathrm{O}$, and $\mathrm{Cu}$ dominate the composition of these novel hierarchical materials. Further quantitative analysis of the EDS reveals that the atomic ratio of $\mathrm{O}: \mathrm{Zn}: \mathrm{Cu}$ is about $10: 9: 1$, indicating that the stoichiometric $[(\mathrm{Zn}+\mathrm{Cu}) / \mathrm{O}=1: 1] \mathrm{CuO} / \mathrm{ZnO}$ hierarchical nanomaterial is consisted of $\mathrm{ZnO}$ and $\mathrm{CuO}$.

The X-ray diffractometer was employed to measure the crystallization of the hydrothermally synthesized $\mathrm{ZnO}$ nanorods and the $\mathrm{CuO} / \mathrm{ZnO}$ hierarchical nanomaterials. As shown in Figure 3, the hydrothermally synthesized $\mathrm{ZnO}$ nanorods were crystallized into a standard hexagonal structure (JCPDS 89-1397) [26]. After $\mathrm{CuO}$ was formed on the $\mathrm{ZnO}$ nanorod, all the dominant peaks of the original $\mathrm{ZnO}$ nanorods were kept, but the peaks of $\mathrm{CuO}(002)$ and $\mathrm{CuO}$ (110) at $2 \theta=39.2^{\circ}$ and $2 \theta=32.6^{\circ}$ appears respectively, and the overlapped peaks of $\mathrm{CuO}$ (111) and $\mathrm{ZnO}$ (101) around $2 \theta=36.4^{\circ}$ also revealed the existence of $\mathrm{CuO}$ in this material and further confirmed that the $\mathrm{CuO}$ nanoparticles 


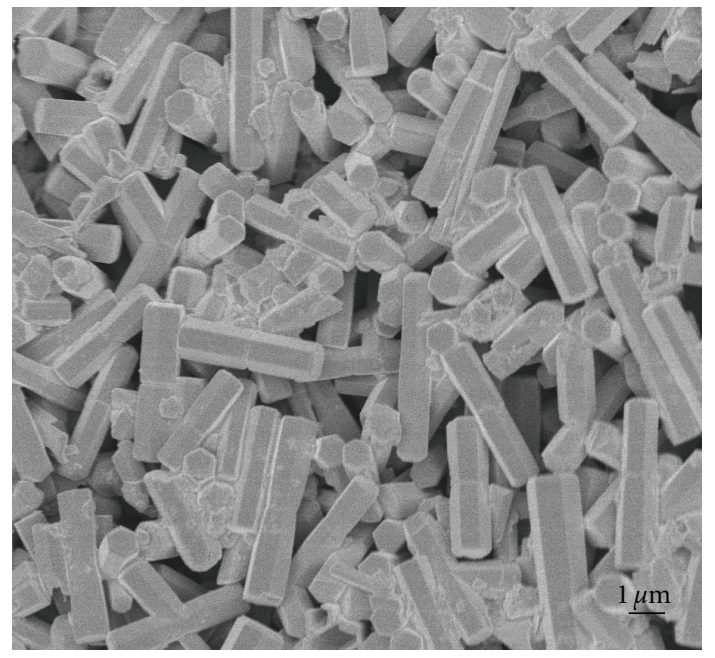

(a)

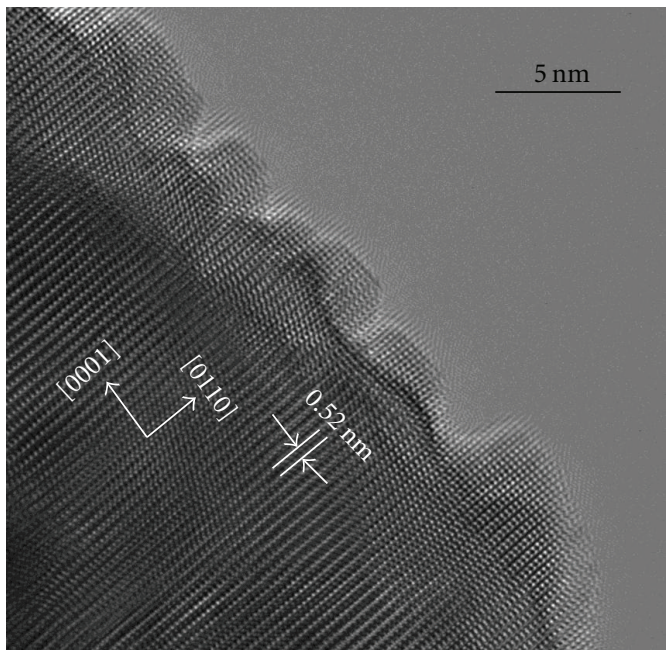

(b)

FIGURE 1: (a) FESEM image and (b) HRTEM image of the hydrothermally synthesized ZnO nanorods.

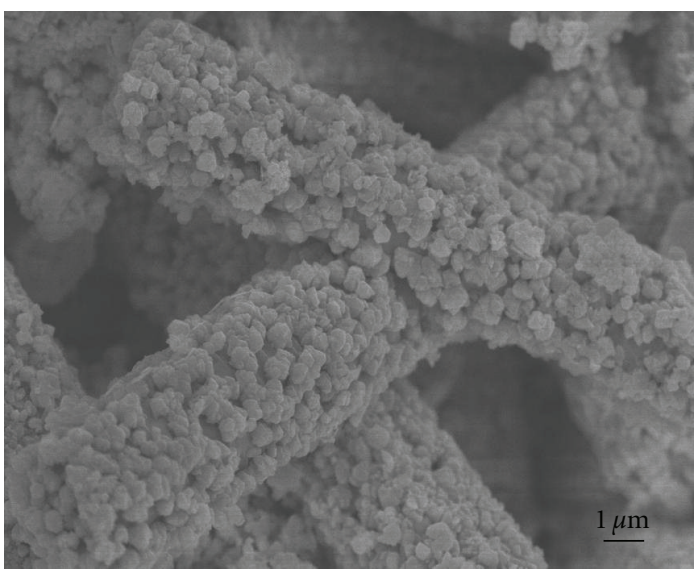

(a)

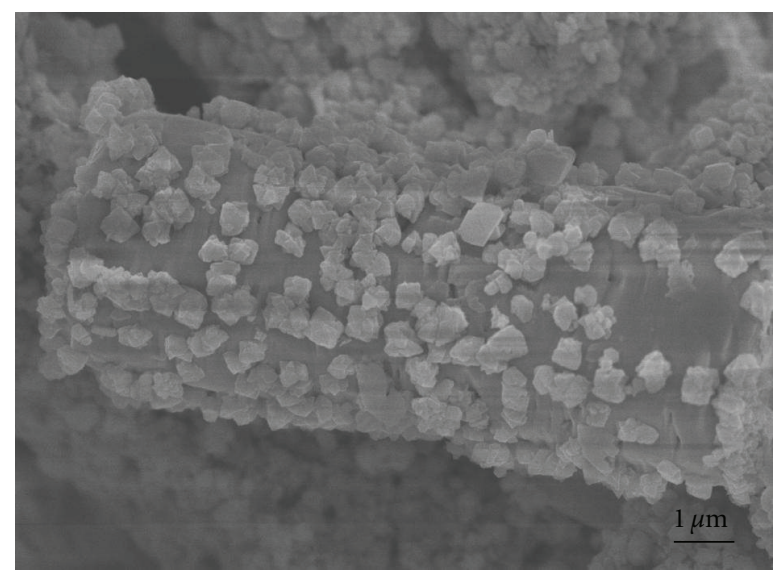

(b)

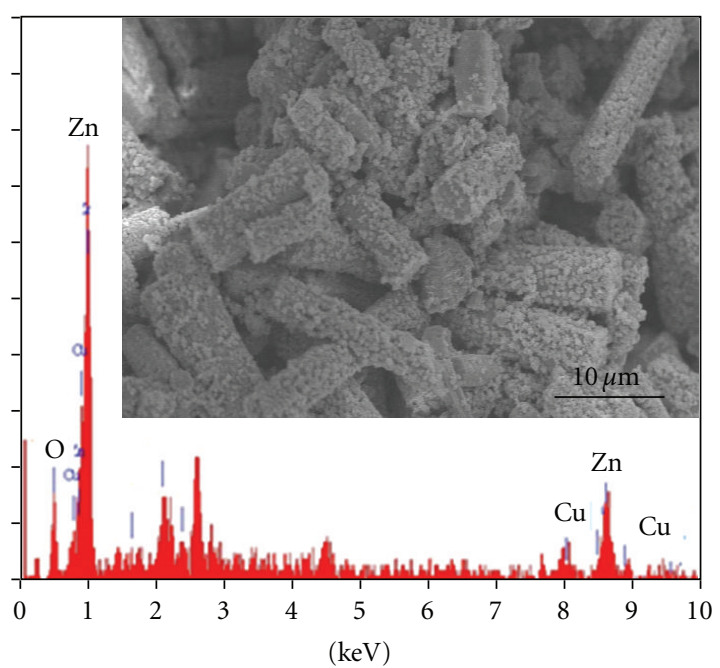

(c)

FIgURE 2: (a)-(b), FESEM images of the hierarchical CuO/ZnO nanomaterials at different magnifications, (c) the EDS spectrum of the hierarchical $\mathrm{CuO} / \mathrm{ZnO}$ nanomaterials, insert is an overview SEM image. 
TABLE 1: Binding energies (eV), fwhm of the hierarchical $\mathrm{CuO} / \mathrm{ZnO}$ nanomaterials.

\begin{tabular}{|c|c|c|c|c|c|c|}
\hline & \multicolumn{2}{|c|}{ Position (fwhm) } & \multicolumn{2}{|c|}{ Position (fwhm) } & \multicolumn{2}{|c|}{ Position (fwhm) } \\
\hline & O $1 \mathrm{~s}$ & O $1 \mathrm{~s}$ & $\mathrm{Zn} 2 \mathrm{p}_{3 / 2}$ & $\mathrm{Zn} 2 \mathrm{p}_{1 / 2}$ & $\mathrm{Cu} 2 \mathrm{p}_{3 / 2}$ & $\mathrm{Cu} 2 \mathrm{p}_{1 / 2}$ \\
\hline $\begin{array}{l}\mathrm{CuO} / \mathrm{ZnO} \text { hierarchical } \\
\text { nanomaterials }\end{array}$ & $\begin{array}{l}530.508 \\
(2.009)\end{array}$ & $\begin{array}{l}532.265 \\
(2.643)\end{array}$ & $\begin{array}{l}1021.45 \\
(3.162)\end{array}$ & $\begin{array}{l}1044.44 \\
(3.027)\end{array}$ & $\begin{array}{l}934.832 \\
(3.559)\end{array}$ & $\begin{array}{l}954.913 \\
(3.656)\end{array}$ \\
\hline
\end{tabular}

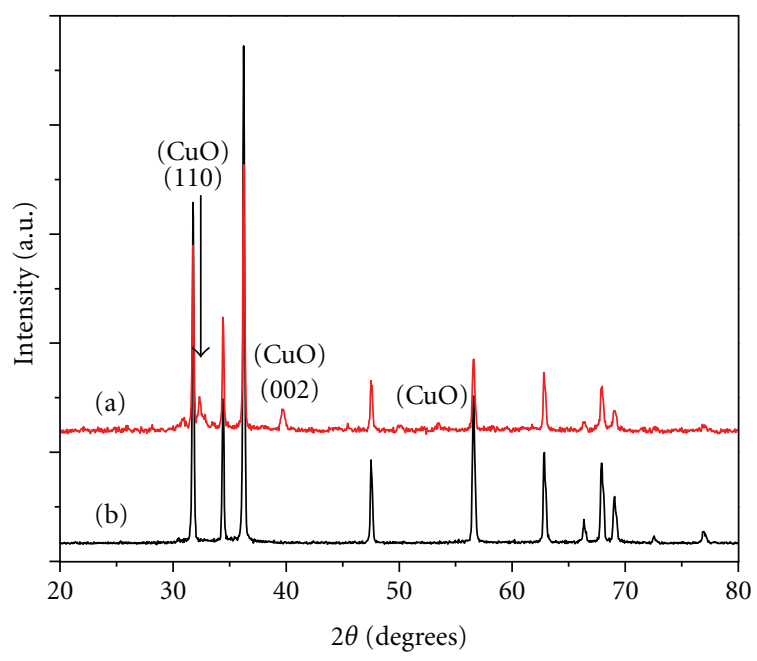

- (a) "corn-like" $\mathrm{CuO} / \mathrm{ZnO}$ material

- (b) $\mathrm{ZnO}$ nanorod

FIGURE 3: XRD patterns of the pure $\mathrm{ZnO}$ nanorods and the hierarchical $\mathrm{CuO} / \mathrm{ZnO}$ nanomaterials.

were uniformly distributed on the surface of this material [27-29].

The chemical composition and electronic structure of the $\mathrm{CuO} / \mathrm{ZnO}$ hierarchical nanomaterials was investigated by $\mathrm{X}$ ray photoelectron spectroscopy (XPS). The XPS spectra of the $\mathrm{Cu} 2 \mathrm{p}, \mathrm{Zn} 2 \mathrm{p}$, and $\mathrm{O} 1 \mathrm{~s}$ were presented in Figure 4 while the detailed binding energies $(\mathrm{eV})$ and their corresponding full width at half maximum (fwhm) were listed in Table 1 . The characteristic intense peaks were centered at $1021.45 \mathrm{eV}$ ( $\mathrm{Zn} \mathrm{2p3/2)} \mathrm{and} \mathrm{1044.44} \mathrm{eV} \mathrm{(Zn} \mathrm{2p1/2)} \mathrm{from} \mathrm{XPS} \mathrm{spectra} \mathrm{of}$ $\mathrm{Zn} 2 \mathrm{p}$ in Figure 4(a), clearly indicating that the oxidation state of $\mathrm{Zn}$ is +2 in the form of $\mathrm{ZnO}$ on the surface of the $\mathrm{CuO} / \mathrm{ZnO}$ hierarchical nanomaterials [30]. The characteristic peaks were located at $934.832(\mathrm{Cu} 2 \mathrm{p} 3 / 2)$ and $954.913(\mathrm{Cu} 2 \mathrm{p} 1 / 2)$, and their corresponding satellite peaks of the $\mathrm{Cu} 2 \mathrm{p}$ XPS spectra presented in Figure 4(b), obviously confirming that the oxidation state of $\mathrm{Cu}$ is +2 in the form of $\mathrm{CuO}$ on the surface of the $\mathrm{CuO} / \mathrm{ZnO}$ hierarchical nanomaterials [31-33]. The broad O 1s peak in Figure 4(c) was comprised of two small peaks, one is located at $530.508 \mathrm{eV}$ and the other one is located at $532.265 \mathrm{eV}$. The former is inherent $\mathrm{O}$ atoms bound to metals such as $\mathrm{Cu}$ and $\mathrm{Zn}$, while the latter peak resulted from the possible surface contaminations by hydroxyl species and carbonate species [34].

The UV-visible spectra of the $\mathrm{CuO} / \mathrm{ZnO}$ hierarchical nanomaterials and $\mathrm{ZnO}$ nanorods were presented in Figure 5. Obviously, the $\mathrm{CuO} / \mathrm{ZnO}$ hierarchical nanomaterials displayed a stronger UV absorption ability over $\mathrm{ZnO}$ nanorods in both UV and visible ranges, which indicates that the UVvisible absorption spectra has been red shifted to visible range. This is because (1) on one hand, the rough surface of the $\mathrm{CuO} / \mathrm{ZnO}$ hierarchical nanomaterials would allow more light reflection and absorption inside the structure [18], which is different from the smooth surface of $\mathrm{ZnO}$ nanorods; (2) on the other hand, $\mathrm{CuO}$ has a potential to red-shift the light absorption spectrum to visible range [16].

The $\mathrm{N}_{2}$ adsorption/desorption isotherm curve of the $\mathrm{CuO} / \mathrm{ZnO}$ hierarchical nanomaterials was measured as shown in Figure 6. Clearly, the $\mathrm{CuO} / \mathrm{ZnO}$ hierarchical nanomaterials show the characteristic mesoporous materials, [35] which is favorable for the mass transfer, light reflection, and bacterial attachment [36]. As measured, the specific surface area of the $\mathrm{CuO} / \mathrm{ZnO}$ hierarchical nanomaterials is $11.24 \mathrm{~m}^{2} / \mathrm{g}$, which is much higher than that of $\mathrm{ZnO}$ nanorods $\left(4.81 \mathrm{~m}^{2} / \mathrm{g}\right)$ and that of commercial $\mathrm{ZnO}$ powder $\left(3 \mathrm{~m}^{2} / \mathrm{g}\right)$ [35].

\subsection{Photodegradation of Contaminants by the Multifunctional} $\mathrm{CuO} / \mathrm{ZnO}$ Membrane. The $\mathrm{CuO} / \mathrm{ZnO}$ membrane, assembled by depositing $\mathrm{CuO} / \mathrm{ZnO}$ nanomaterials on a glassfiber membrane, was tested for the removal of contaminants by photodegradation and filtration. As a blank control, commercial $\mathrm{ZnO}$ powder and physically mixed $\mathrm{CuO} / \mathrm{ZnO}$ nanoparticles were also depositing on glassfiber membranes to investigate their photodegradation abilities of contaminants. Firstly, the photodegradation of industrial dye, such as $\mathrm{MB}$, under the irradiation of visible light on the surface of $\mathrm{CuO} / \mathrm{ZnO}$ membrane was investigated, as shown in Figure 7. MB solution with an initial concentration of $100 \mathrm{ppm}$ was completely degraded after visible light irradiation for $60 \mathrm{~min}$ (Figure 7(a)). $\mathrm{The} \mathrm{CuO} / \mathrm{ZnO}$ membrane demonstrated better photodegradation ability compared with $\mathrm{ZnO}$ membrane and physically mixed $\mathrm{CuO} / \mathrm{ZnO}$ membrane under the same conditions (Figure $7(\mathrm{~b})$ ) because of the special hierarchical $\mathrm{CuO} / \mathrm{ZnO}$ "corn-like" nanostructure [37]. After switching on the vacuum pump as shown in Scheme 1, the MB solution was removed by the concurrent photodegradation and filtration through the assembled membranes. By measuring the permeate from $\mathrm{CuO} / \mathrm{ZnO}$ membrane, $\mathrm{MB}$ was found to be totally removed (after $60 \mathrm{~min}$ reaction), but there was still about $60 \% \mathrm{MB}$ remaining in the permeate from $\mathrm{ZnO}$ membrane (Figure $7(\mathrm{~b})$ ). Moreover, the $\mathrm{CuO} / \mathrm{ZnO}$ membrane is easy to be regenerated after the adsorbed MB was completely degraded by extending the visible light irradiation time.

The $\mathrm{CuO} / \mathrm{ZnO}$ membrane and $\mathrm{ZnO}$ membrane were also tested for the removal of AO7 (Figure 8). The AO7 solution (initial concentration of $50 \mathrm{mg} / \mathrm{L}$ and $\mathrm{pH}$ of 7) was completely photodegraded by the $\mathrm{CuO} / \mathrm{ZnO}$ membrane after $90 \mathrm{~min}$ irradiation of visible light, but longer 


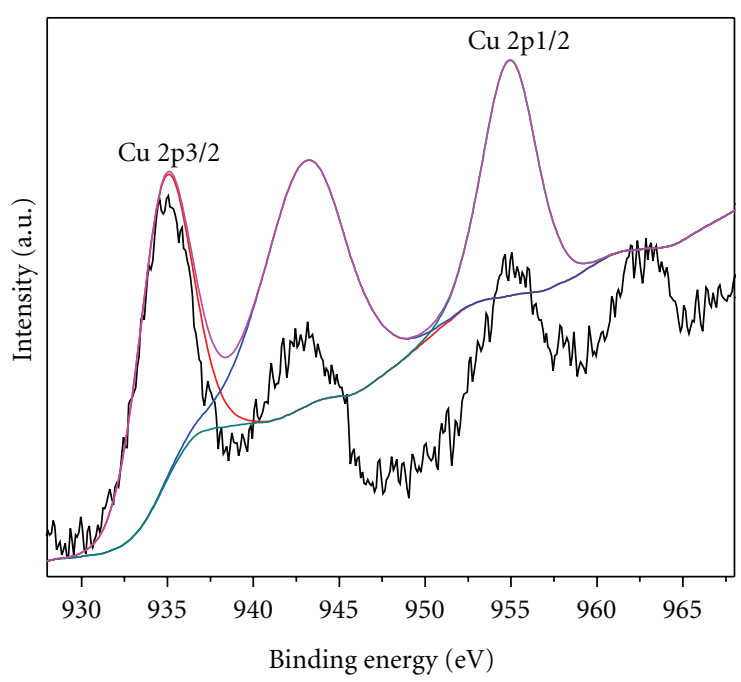

(a)

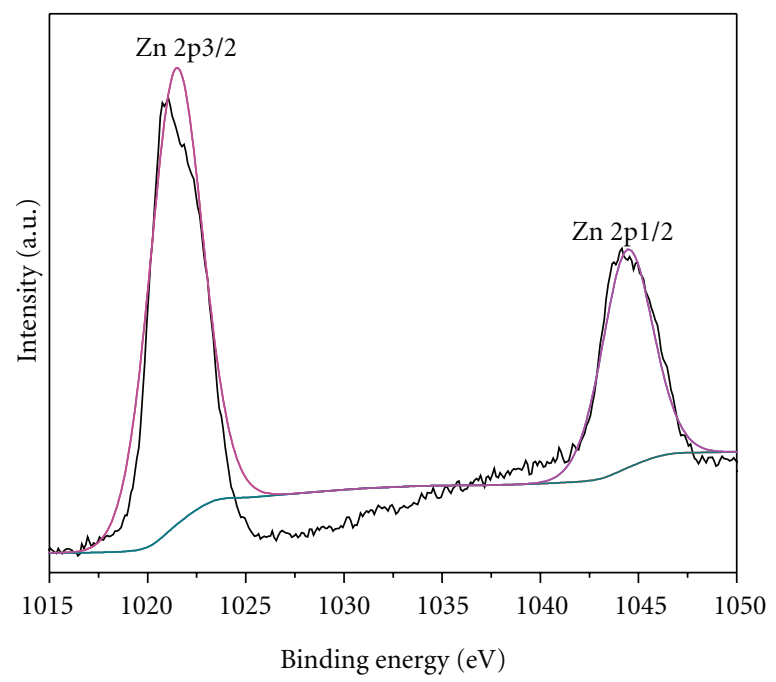

(b)

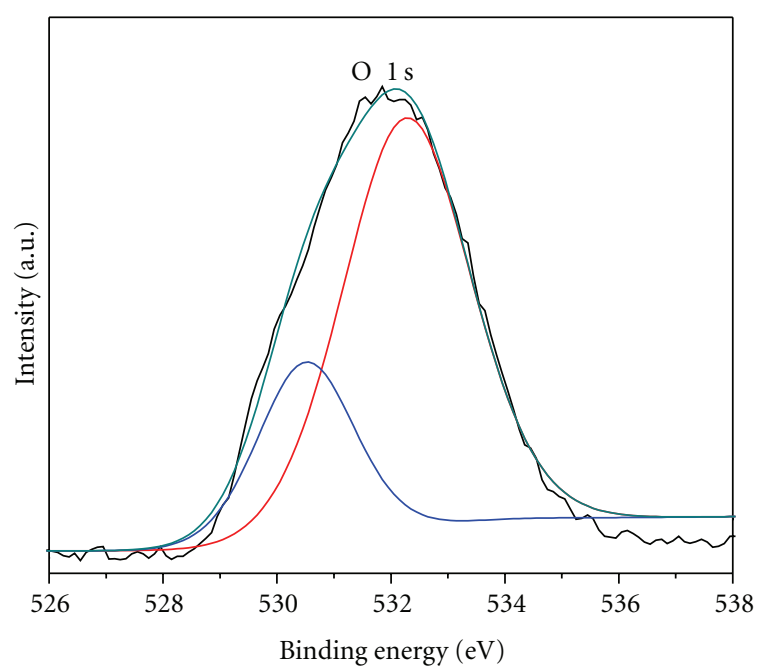

(c)

Figure 4: XPS spectra of the $\mathrm{Cu} 2 \mathrm{p}, \mathrm{Zn} 2 \mathrm{p}$, and $\mathrm{O}$ 1s state on the surface of the hierarchical $\mathrm{CuO} / \mathrm{ZnO}$ nanomaterials.

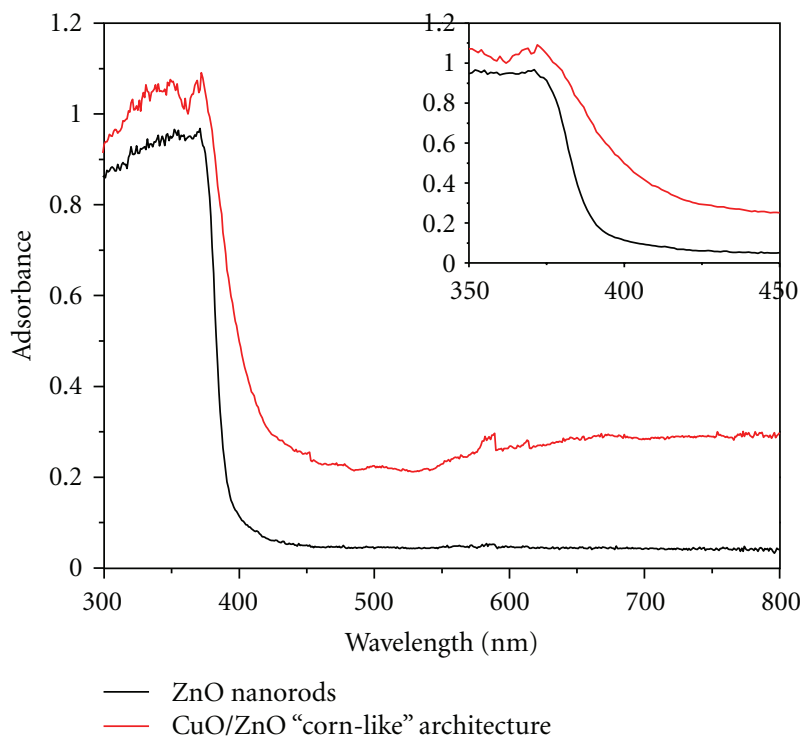

FIgURE 5: The UV-visible spectra of the hierarchical $\mathrm{CuO} / \mathrm{ZnO}$ nanomaterials and $\mathrm{ZnO}$ nanorods. 


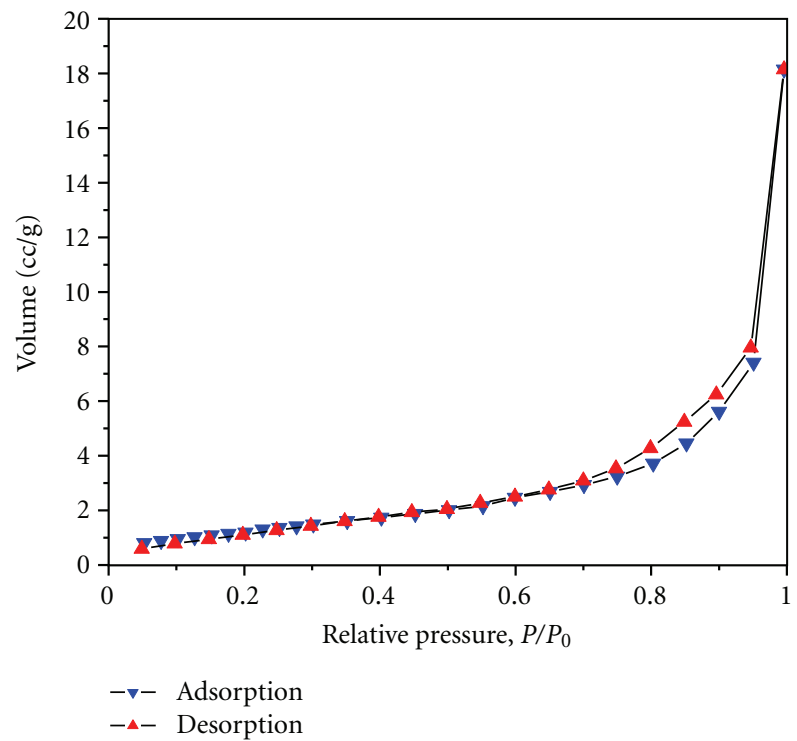

FIGURE 6: $\mathrm{N}_{2}$ adsorption/desorption isotherm curve of the hierarchical $\mathrm{CuO} / \mathrm{ZnO}$ nanomaterials.

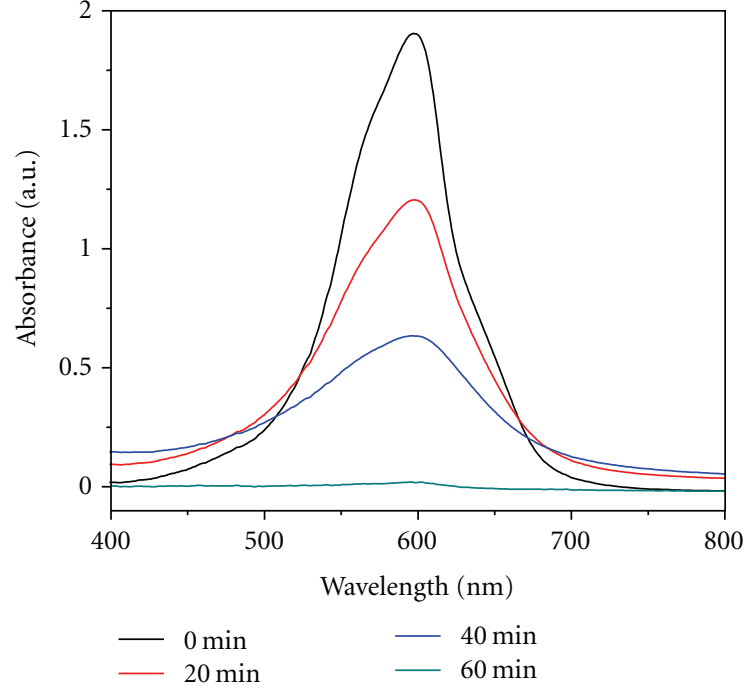

(a)

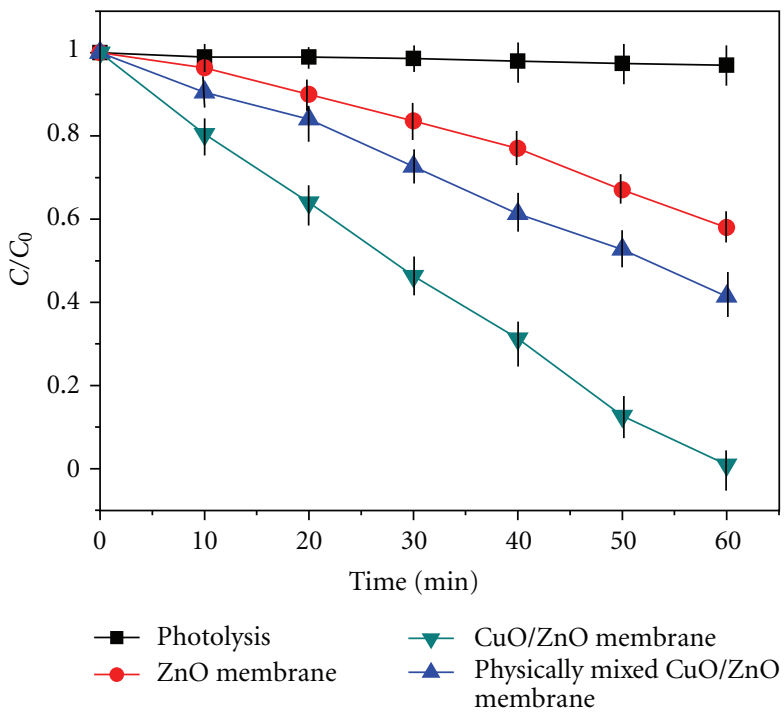

(b)

Figure 7: (a) The absorption spectra of MB solution under the irradiation of visible light on the $\mathrm{CuO} / \mathrm{ZnO}$ membrane, and (b) the concentration change of $\mathrm{MB}$ solution under the irradiation of visible light on the $\mathrm{CuO} / \mathrm{ZnO}$ membrane and $\mathrm{ZnO}$ membrane.

time is needed for the complete degradation of $\mathrm{AO} 7$ by the $\mathrm{ZnO}$ membrane. Through measuring the concentration change of $\mathrm{AO} 7$ during the visible light irradiation process, the $\mathrm{CuO} / \mathrm{ZnO}$ membrane demonstrated better photodegradation ability than that of $\mathrm{ZnO}$ membrane under the same condition (Figure $8(\mathrm{~b})$ ). The concurrent membrane filtration and photocatalysis of $\mathrm{AO} 7$ was also investigated, no $\mathrm{AO} 7$ was found in the permeate from $\mathrm{CuO} / \mathrm{ZnO}$ membrane (after $90 \mathrm{~min}$ ), while there was still $63 \% \mathrm{AO} 7$ found in the permeate from the $\mathrm{ZnO}$ membrane because of pure $\mathrm{ZnO}$ 's low photodegradation ability. At the same time, the $\mathrm{CuO} / \mathrm{ZnO}$ membrane is easy for regeneration after complete photodegradation of AO7 adsorbed on the surface of $\mathrm{CuO} / \mathrm{ZnO}$ membrane by extending the irradiation time of visible light.

The $\mathrm{CuO} / \mathrm{ZnO}$ membrane and $\mathrm{ZnO}$ membrane was also tested for the removal of dye contaminant $\mathrm{RhB}$, the concentration of $\mathrm{RhB}$ was monitored by measuring the UV-visible adsorption value at $553 \mathrm{~nm}$. The concentration change of $\mathrm{RhB}$ under the irradiation of visible light on the $\mathrm{CuO} / \mathrm{ZnO}$ membrane and $\mathrm{ZnO}$ membrane was presented in Figure 9. Obviously, the $\mathrm{CuO} / \mathrm{ZnO}$ membrane demonstrated better photodegradation ability compared with $\mathrm{ZnO}$ membrane. After $120 \mathrm{~min}$ irradiation of visible light, the $\mathrm{CuO} / \mathrm{ZnO}$ membrane completely degraded the $\mathrm{RhB}$ in the solution, while $\mathrm{ZnO}$ membrane only degraded about $45 \%$. 


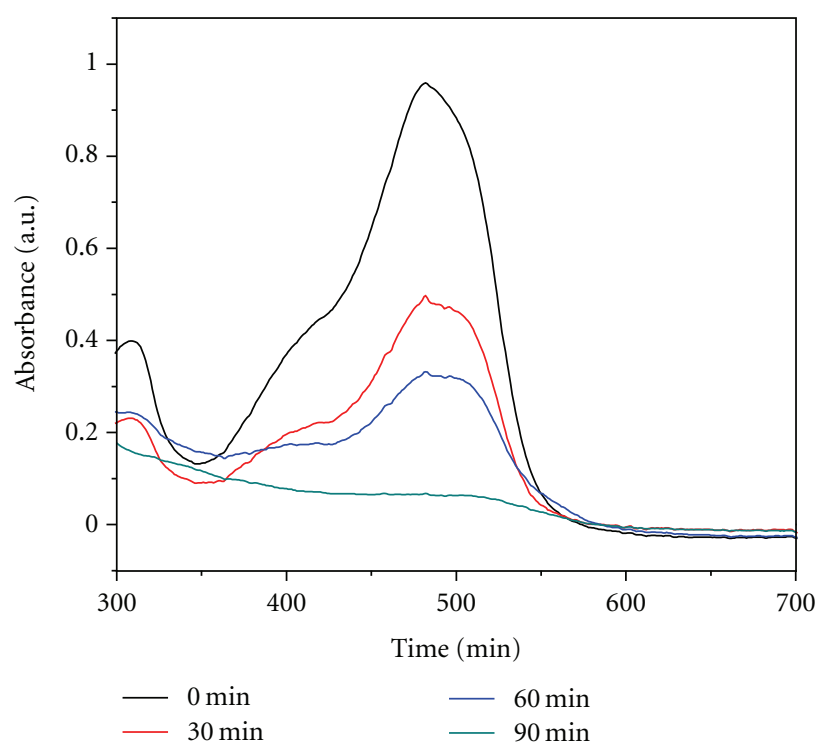

(a)

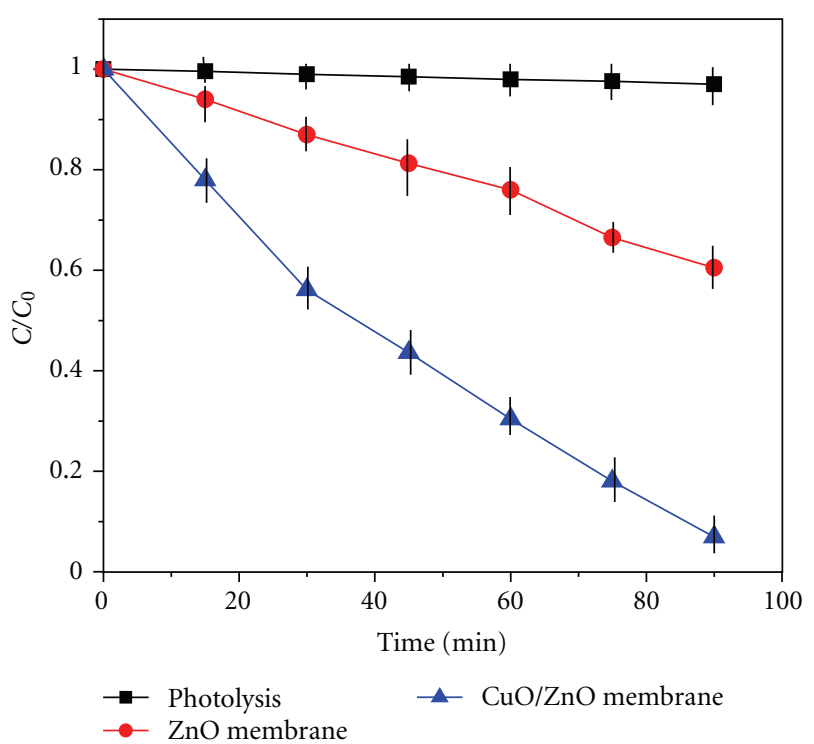

(b)

FIgURE 8: (a) The absorption spectra of AO7 solution under the irradiation of visible light on the $\mathrm{CuO} / \mathrm{ZnO}$ membrane, and (b) the concentration change of $\mathrm{AO} 7$ solution under the irradiation of visible light on the $\mathrm{CuO} / \mathrm{ZnO}$ membrane and $\mathrm{ZnO}$ membrane.

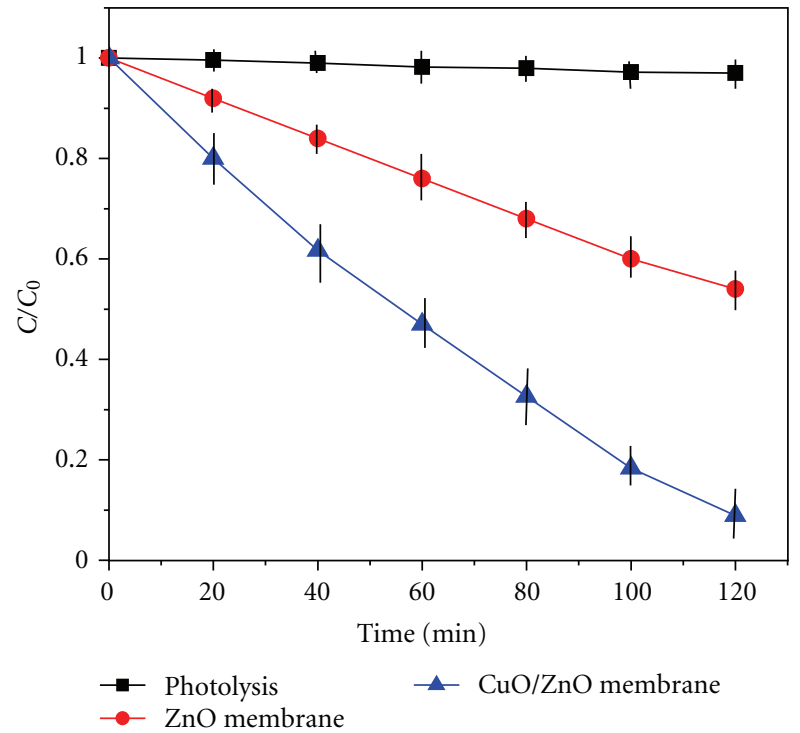

FIGURE 9: The concentration change of RhB under the irradiation of visible light on the $\mathrm{CuO} / \mathrm{ZnO}$ membrane and $\mathrm{ZnO}$ membrane.

The enhanced photodegradation ability of $\mathrm{CuO} / \mathrm{ZnO}$ membrane was attributed to the following reasons. Firstly, the enlarged specific surface area of $\mathrm{CuO} / \mathrm{ZnO}$ nanomaterials $\left(11.24 \mathrm{~m}^{2} / \mathrm{g}\right)$ over that of $\mathrm{ZnO}$ nanorods $\left(4.81 \mathrm{~m}^{2} / \mathrm{g}\right)$ is favorable for contaminant adsorption, providing more reaction sites for the photocatalytic reactions. Secondly, the $\mathrm{CuO} / \mathrm{ZnO}$ nanomaterials improved the light utilization rate compared with $\mathrm{ZnO}$ nanorods. The rough surface of $\mathrm{CuO} / \mathrm{ZnO}$ nanomaterials can enhance the light reflection and absorption inside the $\mathrm{CuO} / \mathrm{ZnO}$ nanomaterials, while on the contrast, $\mathrm{ZnO}$ nanorods only can be excited by UV

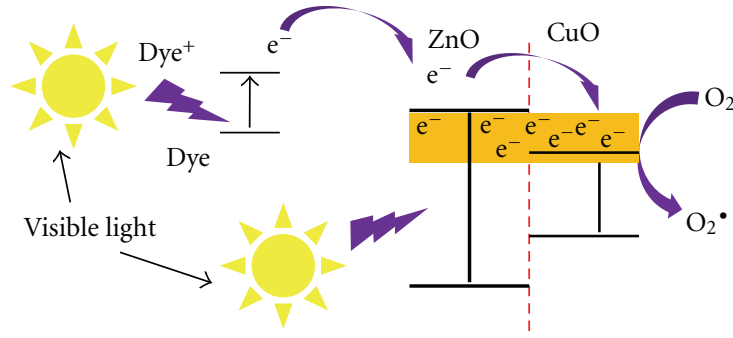

Scheme 2: Schematic diagram of the electron transfer and the energy band positions of $\mathrm{ZnO}$ and $\mathrm{CuO}$ in the hierarchical $\mathrm{CuO} / \mathrm{ZnO}$ materials for the photodegradation of dye contaminants under the irradiation of visible light.

light which just accounts for a minor part of the solar light [16]. Moreover, the $\mathrm{CuO} / \mathrm{ZnO}$ hierarchical nanomaterial with larger specific surface area favors the adsorption of dye contaminants, the adsorbed dye contaminants is favorable for the utilization of visible light $[38,39]$, and the produced electrons and holes would be transferred to $\mathrm{CuO} / \mathrm{ZnO}$ nanomaterials [40]. The transferred electrons were captured by the surface adsorbed $\mathrm{O}_{2}$ to yield $\mathrm{O}_{2}{ }^{-}$and $\mathrm{HOO}^{\bullet}$ radicals [40]. Then the dye contaminants are photodegraded in situ by the produced radicals. At the same time, the band gap difference between $\mathrm{CuO}$ and $\mathrm{ZnO}$ facilitates the transfer of photogenerated electrons and holes from $\mathrm{ZnO}$ to $\mathrm{CuO}$ (Scheme 2) [8]; in this way, the recombination of electrons and holes is retarded to a certain extent [41]. Therefore, the photocatalytic activity is enhanced.

3.2. Antibacterial Capability Test. Besides the photodegradation of contaminants, the antibacterial capabilities of the $\mathrm{CuO} / \mathrm{ZnO}$ membrane and $\mathrm{ZnO}$ membrane were also investigated. Figure 10 shows the inactivation of E. coli on 


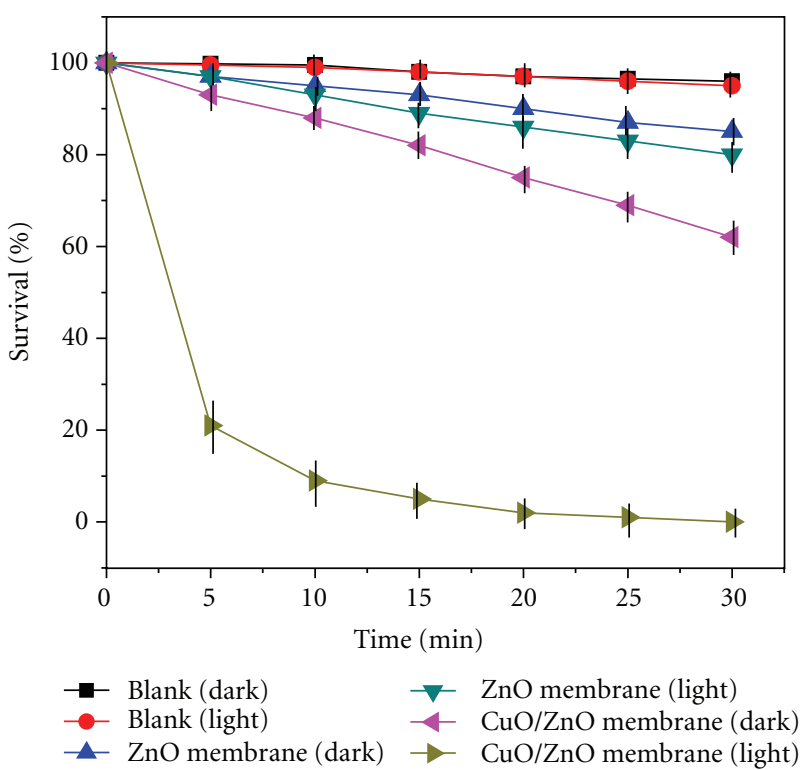

Figure 10: Plot of \% E. coli survival rate as the function of visible light irradiation time on $\mathrm{CuO} / \mathrm{ZnO}$ membrane and $\mathrm{ZnO}$ membrane.

the $\mathrm{CuO} / \mathrm{ZnO}$ membrane and $\mathrm{ZnO}$ membrane with/without the irradiation of visible light. The survival of $E$. coli can be calculated by $\%$ survival $=B / A * 100$ (where $A$ is the number of surviving microbial colonies in the control, and $B$ is the number of surviving microbial colonies in the tested sample). To rule out the synergic effect of $\mathrm{CuO} / \mathrm{ZnO}$ membrane on the inactivation of E. coli, both blank control experiments for the pure glassfiber membrane and inactivation of $E$. coli by $\mathrm{ZnO}$ membrane with/without the irradiation were conducted using the same method. It is found that the direct visible light irradiation has no obvious effect on the inactivation of $E$. coli on pure glassfiber membrane. As we know, $\mathrm{ZnO}$ [3] and $\mathrm{CuO}$ [17] have certain antibacterial growth ability; hence, both $\mathrm{CuO} / \mathrm{ZnO}$ membrane and $\mathrm{ZnO}$ membrane demonstrated antibacterial growth in the dark as expected. However, under the irradiation of visible light, the antibacterial capability of $\mathrm{CuO} / \mathrm{ZnO}$ membrane was greatly enhanced and was significantly higher than that of $\mathrm{ZnO}$ membrane; wherein, $\mathrm{CuO} / \mathrm{ZnO}$ membrane can completely kill all the E. coli in the solution after 20 min irradiation of visible light, while $\mathrm{ZnO}$ membrane can only kill around $40 \%$ E. coli even after $30 \mathrm{~min}$ irradiation of visible light. This indicates that the synergic effect of $\mathrm{CuO} / \mathrm{ZnO}$ nanomaterials played a significant role in the improvement of antibacterial capability, which is in consistent with previous reports [42]. The enhanced antibacterial capability is attributed to (1) the enlarged specific surface area and mesoporous property [36] of $\mathrm{CuO} / \mathrm{ZnO}$ nanomaterial which is convenient for bacterial attachment and (2) the enhanced photocatalytic activity by enlarging the light utilization rate and retarding the recombination of photogenerated electrons and holes between $\mathrm{CuO}$ and $\mathrm{ZnO}$, as explained in previous section $[8,16]$.

\section{Conclusion}

The hierarchical $\mathrm{CuO} / \mathrm{ZnO}$ nanomaterials have been successfully synthesized for the first time by the combination of low-hydrothermal and photodeposition methods. This hierarchical $\mathrm{CuO} / \mathrm{ZnO}$ nanomaterial was well characterized by FESEM, TEM, XRD, XPS, and so forth. The $\mathrm{CuO} / \mathrm{ZnO}$ membrane was assembled by depositing the hierarchical $\mathrm{CuO} / \mathrm{ZnO}$ nanomaterials on the surface of glassfiber membrane with the help of vacuum filtration. The $\mathrm{CuO} / \mathrm{ZnO}$ membrane demonstrated high photodegradation ability for dye contaminants, such as $\mathrm{MB}, \mathrm{AO}$, and $\mathrm{RhB}$, under visible light irradiation, which results from the enlarged specific surface area for contaminants adsorption, the improved light utilization rate, and the retarded recombination of electrons and holes. At the same time, the $\mathrm{CuO} / \mathrm{ZnO}$ membrane is easy for regeneration by complete degradation the adsorbed dyes with extending the visible light irradiation time. Furthermore, the $\mathrm{CuO} / \mathrm{ZnO}$ membrane also demonstrated better antibacterial capability than $\mathrm{ZnO}$ membrane due to the synergic effect of $\mathrm{CuO} / \mathrm{ZnO}$ nanomaterials. All these advantages of the $\mathrm{CuO} / \mathrm{ZnO}$ membrane would bring great benefits to water purification applications.

\section{Acknowledgment}

The authors are grateful for the financial support received from the National Research Foundation/NTU Joint R\&D (REF. COY-25-24/N370-4).

\section{References}

[1] M. A. Shannon, P. W. Bohn, M. Elimelech, J. G. Georgiadis, B. J. Marinas, and A. M. Mayes, "Science and technology for water purification in the coming decades," Nature, vol. 452, no. 7185, pp. 301-310, 2008.

[2] X. Huang, M. Leal, and Q. Li, "Degradation of natural organic matter by $\mathrm{TiO}_{2}$ photocatalytic oxidation and its effect on fouling of low-pressure membranes," Water Research, vol. 42, no. 4-5, pp. 1142-1150, 2008.

[3] Q. Li, S. Mahendra, D. Y. Lyon et al., "Antimicrobial nanomaterials for water disinfection and microbial control: potential applications and implications," Water Research, vol. 42, no. 18, pp. 4591-4602, 2008.

[4] R. Asahi, T. Morikawa, T. Ohwaki, K. Aoki, and Y. Taga, "Visible-light photocatalysis in nitrogen-doped titanium oxides," Science, vol. 293, no. 5528, pp. 269-271, 2001.

[5] A. Fujishima, X. Zhang, and D. A. Tryk, " $\mathrm{TiO}_{2}$ photocatalysis and related surface phenomena," Surface Science Reports, vol. 63, no. 12, pp. 515-582, 2008.

[6] X. Zhang, J. H. Pan, A. J. Du, W. Fu, D. D. Sun, and J. O. Leckie, "Combination of one-dimensional $\mathrm{TiO}_{2}$ nanowire photocatalytic oxidation with microfiltration for water treatment," Water Research, vol. 43, no. 5, pp. 1179-1186, 2009.

[7] J. Yu and X. Yu, "Hydrothermal synthesis and photocatalytic activity of zinc oxide hollow spheres," Environmental Science \& Technology, vol. 42, no. 13, pp. 4902-4907, 2008.

[8] S. Wei, Y. Chen, Y. Ma, and Z. Shao, "Fabrication of $\mathrm{CuO} / \mathrm{ZnO}$ composite films with cathodic co-electrodeposition and their photocatalytic performance," Journal of Molecular Catalysis A, vol. 331, no. 1-2, pp. 112-116, 2010. 
[9] Z. Liu, D. D. Sun, P. Guo, and J. O. Leckie, "An efficient bicomponent $\mathrm{TiO}_{2} / \mathrm{SnO}_{2}$ nanofiber photocatalyst fabricated by electrospinning with a side-by-side dual spinneret method," Nano Letters, vol. 7, no. 4, pp. 1081-1085, 2007.

[10] X. Qiu, G. Li, X. Sun, L. Li, and X. Fu, "Doping effects of $\mathrm{Co}^{2+}$ ions on $\mathrm{ZnO}$ nanorods and their photocatalytic properties," Nanotechnology, vol. 19, no. 21, Article ID 215703, 2008.

[11] S. Liu, C. Li, J. Yu, and Q. Xiang, "Improved visible-light photocatalytic activity of porous carbon self-doped $\mathrm{ZnO}$ nanosheet-assembled flowers," CrystEngComm, vol. 13, pp. 2533-2541, 2011.

[12] P. Sharma, P. Kumar, D. Deva, R. Shrivastav, S. Dass, and V. R. Satsangi, "Nanostructured $\mathrm{Zn}-\mathrm{Fe} 2 \mathrm{O} 3$ thin film modified by $\mathrm{Fe}-\mathrm{TiO} 2$ for photoelectrochemical generation of hydrogen," International Journal of Hydrogen Energy, vol. 35, no. 20, pp. 10883-10889, 2010.

[13] T. Arai, M. Yanagida, Y. Konishi, Y. Iwasaki, H. Sugihara, and K. Sayama, "Promotion effect of $\mathrm{CuO}$ co-catalyst on $\mathrm{WO}_{3}$ catalyzed photodegradation of organic substances," Catalysis Communications, vol. 9, no. 6, pp. 1254-1258, 2008.

[14] C. Lévy-Clément, R. Tena-Zaera, M. A. Ryan, A. Katty, and G. Hodes, "CdSe-sensitized p-CuSCN/nanowire n-ZnO heterojunctions," Advanced Materials, vol. 17, no. 12, pp. 1512-1515, 2005.

[15] N. Helaili, Y. Bessekhouad, A. Bouguelia, and M. Trari, "p$\mathrm{Cu}_{2} \mathrm{O} / \mathrm{n}-\mathrm{ZnO}$ heterojunction applied to visible light Orange II degradation," Solar Energy, vol. 84, no. 7, pp. 1187-1192, 2010.

[16] B. Li and Y. Wang, "Facile synthesis and photocatalytic activity of $\mathrm{ZnO}-\mathrm{CuO}$ nanocomposite," Superlattices and Microstructures, vol. 47, no. 5, pp. 615-623, 2010.

[17] M. Heinlaan, A. Ivask, I. Blinova, H. C. Dubourguier, and A. Kahru, "Toxicity of nanosized and bulk $\mathrm{ZnO}, \mathrm{CuO}$ and $\mathrm{TiO}_{2}$ to bacteria Vibrio fischeri and crustaceans Daphnia magna and Thamnocephalus platyurus," Chemosphere, vol. 71, no. 7, pp. 1308-1316, 2008.

[18] H. Bai, Z. Liu, and D. D. Sun, "Hierarchically multifunctional $\mathrm{TiO}_{2}$ nano-thorn membrane for water purification," Chemical Communications, vol. 46, no. 35, pp. 6542-6544, 2010.

[19] H. Bai, X. Zhang, J. Pan, D. D. Sun, and J. Shao, "Combination of nano $\mathrm{TiO}_{2}$ photocatalytic oxidation with microfiltration (MF) for natural organic matter removal," Water Science and Technology, vol. 9, no. 1, pp. 31-37, 2009.

[20] X. Zhang, A. J. Du, P. Lee, D. D. Sun, and J. O. Leckie, " $\mathrm{TiO}_{2}$ nanowire membrane for concurrent filtration and photocatalytic oxidation of humic acid in water," Journal of Membrane Science, vol. 313, no. 1-2, pp. 44-51, 2008.

[21] Q. Li, V. Kumar, Y. Li, H. Zhang, T. J. Marks, and R. P. H. Chang, "Fabrication of $\mathrm{ZnO}$ nanorods and nanotubes in aqueous solutions," Chemistry of Materials, vol. 17, no. 5, pp. 1001-1006, 2005.

[22] B. Liu and H. C. Zeng, "Hydrothermal synthesis of $\mathrm{ZnO}$ nanorods in the diameter regime of $50 \mathrm{~nm}$," Journal of the American Chemical Society, vol. 125, no. 15, pp. 4430-4431, 2003.

[23] X. Feng, L. Feng, M. Jin, J. Zhai, L. Jiang, and D. Zhu, 'Reversible super-hydrophobicity to super-hydrophilicity transition of aligned ZnO nanorod films," Journal of the American Chemical Society, vol. 126, no. 1, pp. 62-63, 2004.

[24] A. Filankembo, S. Giorgio, I. Lisiecki, and M. P. Pileni, "Is the anion the major parameter in the shape control of nanocrystals?" Journal of Physical Chemistry B, vol. 107, no. 9, pp. 74927500, 2003.

[25] K. Sunada, T. Watanabe, and K. Hashimoto, "Bactericidal activity of copper-deposited $\mathrm{TiO}_{2}$ thin film under weak UV light illumination," Environmental Science and Technology, vol. 37, no. 20, pp. 4785-4789, 2003.

[26] U. Pal and P. Santiago, "Controlling the morphology of $\mathrm{ZnO}$ nanostructures in a low-temperature hydrothermal process," Journal of Physical Chemistry B, vol. 109, no. 32, pp. 1531715321, 2005.

[27] N. Wu, M. Zhao, J. G. Zheng et al., "Porous CuO-ZnO nanocomposite for sensing electrode of high-temperature $\mathrm{CO}$ solid-state electrochemical sensor," Nanotechnology, vol. 16, no. 12, pp. 2878-2881, 2005.

[28] S. M. Zhou, X. H. Zhang, X. M. Meng et al., "The fabrication and optical properties of highly crystalline ultra-long $\mathrm{Cu}-$ doped ZnO nanowires," Nanotechnology, vol. 15, no. 9, pp. 1152-1155, 2004.

[29] G. K. Mor, O. K. Varghese, R. H. T. Wilke et al., "p-type Cu-Ti$\mathrm{O}$ nanotube arrays and their use in self-biased heterojunction photoelectrochemical diodes for hydrogen generation," Nano Letters, vol. 8, no. 7, pp. 1906-1911, 2008.

[30] Y. Myung, D. M. Jang, T. K. Sung et al., "Composition-tuned $\mathrm{ZnO}-\mathrm{CdSSe}$ Core-Shell nanowire arrays," ACS Nano, vol. 4, no. 7, pp. 3789-3800, 2010.

[31] Y. G. Zhang, L. L. Ma, J. L. Li, and Y. Yu, "In situ Fenton reagent generated from $\mathrm{TiO}_{2} / \mathrm{Cu}_{2} \mathrm{O}$ composite film: a new way to utilize $\mathrm{TiO}_{2}$ under visible light irradiation," Environmental Science and Technology, vol. 41, no. 17, pp. 6264-6269, 2007.

[32] J. Yu and J. Ran, "Facile preparation and enhanced photocatalytic $\mathrm{H}_{2}$-production activity of $\mathrm{Cu}(\mathrm{OH})_{2}$ cluster modified $\mathrm{TiO}_{2}$," Energy and Environmental Science, vol. 4, pp. 13641371, 2011.

[33] J. Yu, Y. Hai, and M. Jaroniec, "Photocatalytic hydrogen production over CuO-modified titania," Journal of Colloid and Interface Science, vol. 357, no. 1, pp. 223-228, 2011.

[34] J. Ng, S. Xu, X. Zhang, H. Y. Yang, and D. D. Sun, "Hybridized nanowires and cubes: a novel architecture of a heterojunctioned $\mathrm{TiO}_{2} / \mathrm{SrTiO}_{3}$ thin film for efficient water splitting," Advanced Functional Materials, vol. 20, no. 24, pp. 4287-4294, 2010.

[35] C. M. Janet, S. Navaladian, B. Viswanathan, T. K. Varadarajan, and R. P. Viswanath, "Heterogeneous wet chemical synthesis of superlattice-type hierarchical $\mathrm{ZnO}$ architectures for concurrent $\mathrm{H}_{2}$ production and $\mathrm{N}_{2}$ reduction," Journal of Physical Chemistry C, vol. 114, no. 6, pp. 2622-2632, 2010.

[36] H. Oveisi, S. Rahighi, X. Jiang et al., "Unusual antibacterial property of mesoporous titania films: drastic improvement by controlling surface area and crystallinity," Chemistry, vol. 5, no. 9, pp. 1978-1983, 2010.

[37] H. Bai, Z. Liu, and D. D. Sun, "Hierarchical $\mathrm{ZnO} / \mathrm{Cu}$ "cornlike" materials with high photodegradation and antibacterial capability under visible light," Physical Chemistry Chemical Physics, vol. 13, no. 13, pp. 6205-6210, 2011.

[38] D. Chatterjee and S. Dasgupta, "Visible light induced photocatalytic degradation of organic pollutants," Journal of Photochemistry and Photobiology C, vol. 6, no. 2-3, pp. 186205, 2005.

[39] G. Liu, G. Li, X. Qiu, and L. Li, "Synthesis of ZnO/titanate nanocomposites with highly photocatalytic activity under visible light irradiation," Journal of Alloys and Compounds, vol. 481, no. 1-2, pp. 492-497, 2009.

[40] K. Vinodgopal, D. E. Wynkoop, and P. V. Kamat, "Environmental photochemistry on semiconductor surfaces: photosensitized degradation of a textile azo dye, Acid Orange 7, on $\mathrm{TiO}_{2}$ particles using visible light," Environmental Science and Technology, vol. 30, no. 5, pp. 1660-1666, 1996. 
[41] G. Li, N. M. Dimitrijevic, L. Chen, T. Rajh, and K. A. Gray, "Role of surface/interfacial $\mathrm{Cu}^{2+}$ sites in the photocatalytic activity of coupled $\mathrm{CuO}-\mathrm{TiO}_{2}$ nanocomposites," Journal of Physical Chemistry C, vol. 112, no. 48, pp. 19040-19044, 2008.

[42] H. Kong, J. Song, and J. Jang, "Photocatalytic antibacterial capabilities of $\mathrm{TiO}_{2}$-biocidal polymer nanocomposites synthesized by a surface-initiated photopolymerization," Environmental Science \& Technology, vol. 44, no. 14, pp. 5672-5676, 2010. 


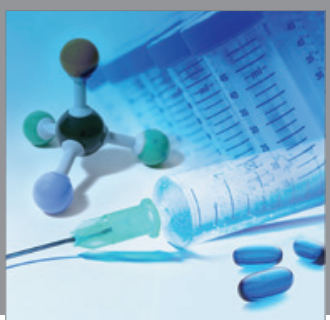

International Journal of

Medicinal Chemistry

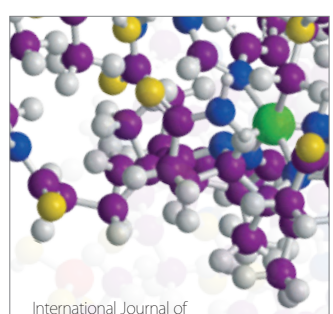

Carbohydrate Chemistry

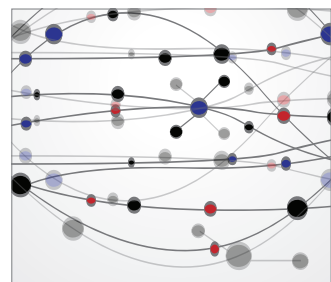

The Scientific World Journal
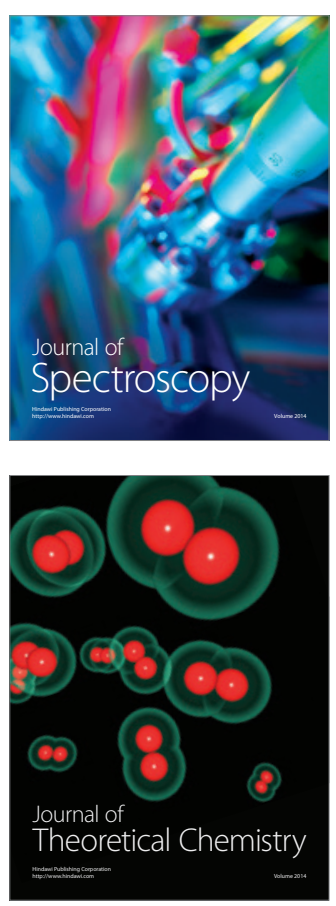
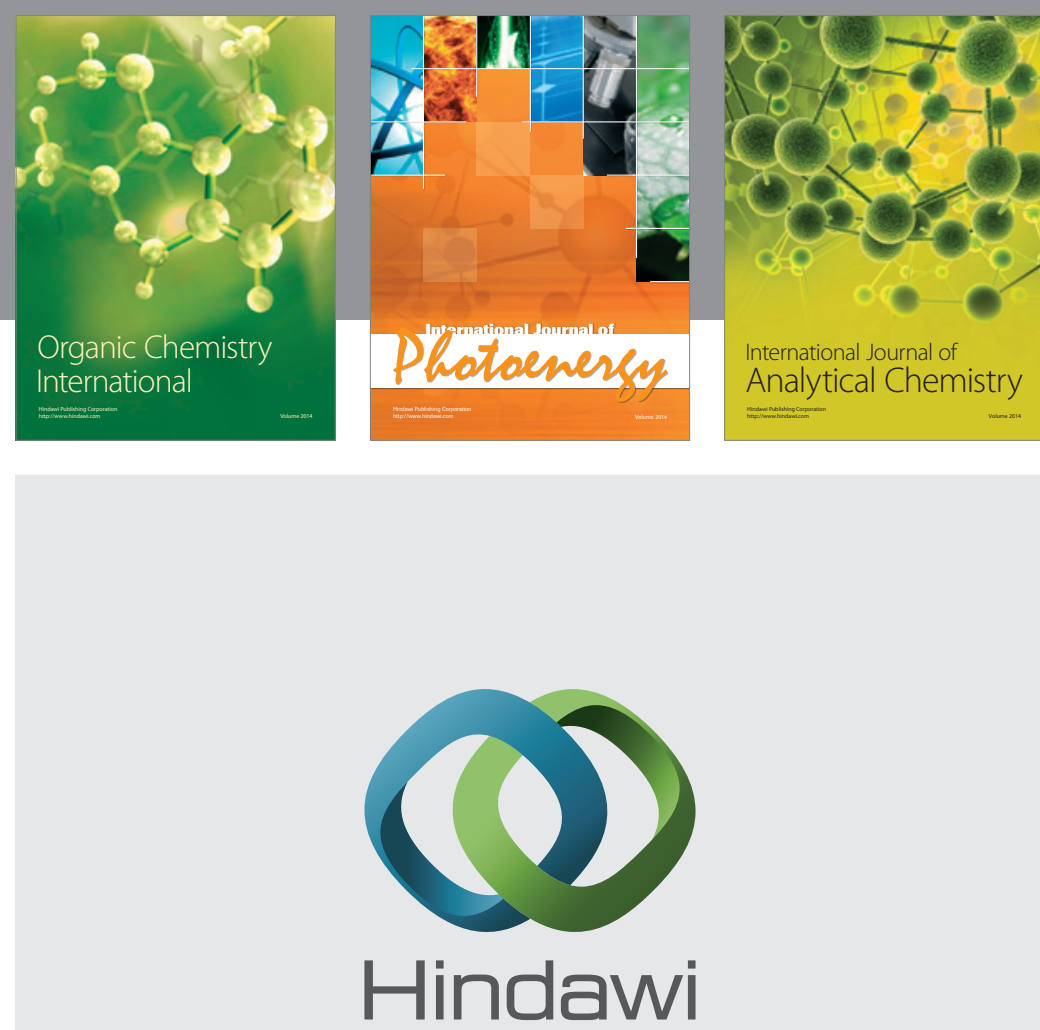

Submit your manuscripts at

http://www.hindawi.com
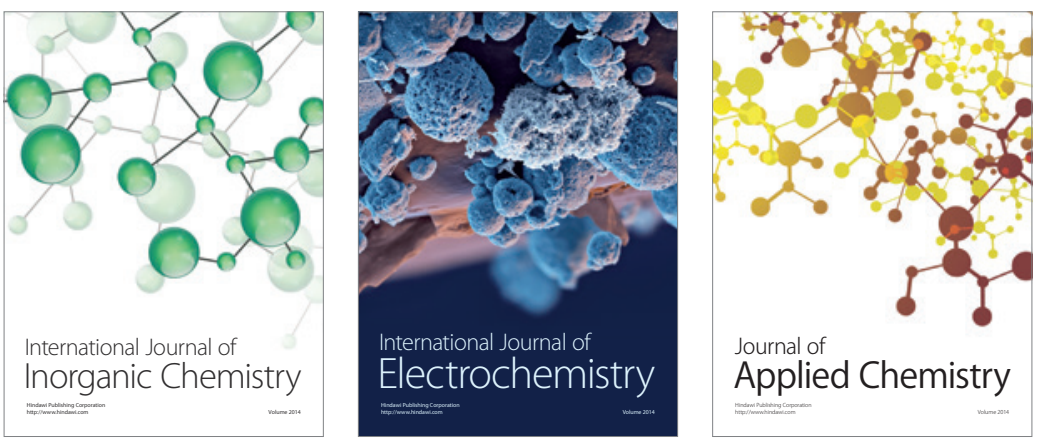

Journal of

Applied Chemistry
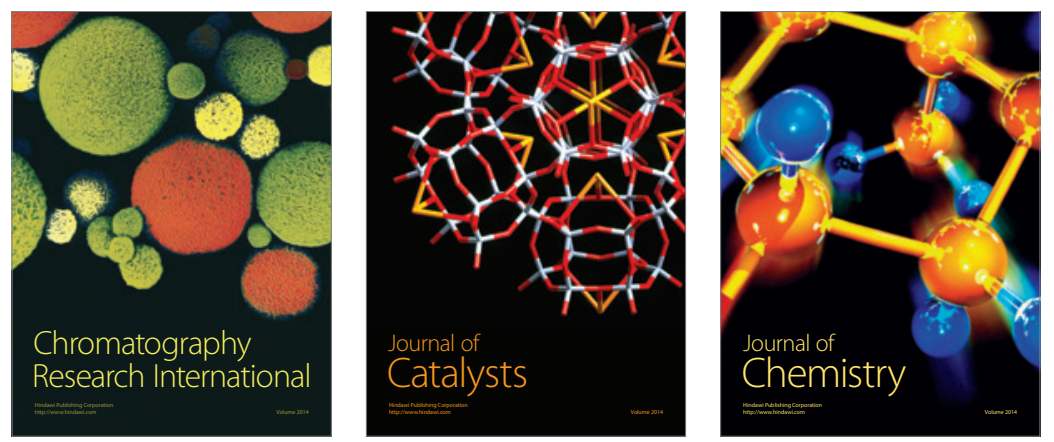
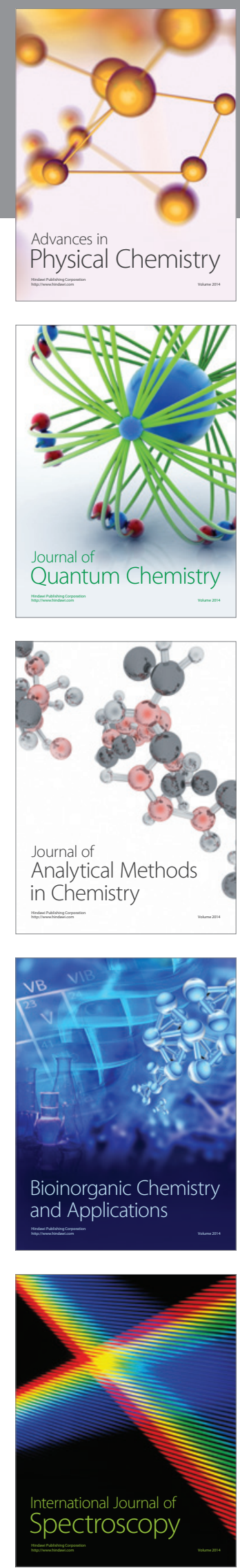